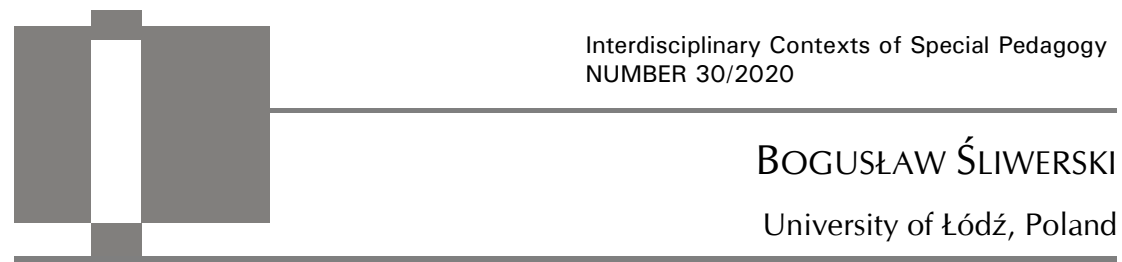

\title{
Montessori Pedutology
}

ABSTRACT: Bogusław Śliwerski, Montessori Pedutology. Interdisciplinary Contexts of Special Pedagogy, no. 30, Poznań 2020. Pp. 7-31. Adam Mickiewicz University Press. ISSN 2300-391X. e-ISSN 2658-283X. DOI: https:// doi.org/10.14746/ikps.2020.30.01

The subject of the analysis is the reception of Montessori education in post-socialist Poland. The author focuses mainly on the models of pedeutological research to emphasise the important role played by the teacher as a professional, educator, but also a human being in this alternative upbringing and education. He recalls the most important results of research on the specificity of teaching work in Montessori institutions.

KEY WORDS: education, alternative education, teacher, Montessori pedagogy, teacher research models, pedeutology

\section{Introduction}

Thirty years ago, a renaissance of Montessori education in preschool education of post-socialist countries in the spirit of personalism and educational principles of didactic constructivism took place. Each of the waves of renewed interest in this education originated from the fact that it was excluded from Polish educational institutions during the period of two totalitarianisms - Nazi and Soviet ones, in 1939-1989. The concept of the child as an autonomous being in its development, who had to be helped in the art of discovering one's own freedom and using it responsibly, was unac- 
ceptable to the authorities of the time. Only the transformation of the political system in 1989, and the consequent liquidation of political, and ideological censorship exercised by the Main Office for the Control of the Press, Publications, and Public Performances finally allowed for the translation into Polish or extraction from the archives of forbidden collections, scientific and methodological dissertations on the application of Maria Montessori education in Poland and all over the world.

\section{Łódź school for research on the reception and updating of Montessori education in theory and practice}

The fascination with this kind of education and its application in teaching practice took place during the Second Polish Republic, when the first Montessori kindergartens were established in numerous places in Poland. Polish teachers, studying or staying abroad, participated in Montessori courses in Rome and London, and even co-created the first Montessori schools in Italy. Their knowledge and experience penetrated into the country thanks to numerous enthusiasts of this concept of education. Interestingly, this kind of education aroused great interest among the supporters of home education, who adapted it to their own needs and national spirit.

Ewa Łatacz from the University of Łódź wrote in her dissertation about the delight with pedagogy of New Education annoying traditionalists in the interwar period in Poland. ${ }^{1}$ Numerous opponents of this pedagogy must have been surprised by the discovery of the Lódź historian of education of the delight, expressed among others by blessed Urszula Ledóchowska, but also the superiors of the Jesuit order in our country, with this concept, and even the establishment of nurseries or kindergartens for children, in which not

${ }^{1}$ E. Łatacz, Recepcja teorii pedagogicznej Marii Montessori w Polsce do roku 1939, Łódź 1996. 
only the educational methods of Decroly or Froebel, but also of Montessori were used.

Thanks to the research results of Ewa Łatacz, at the beginning of the 1990s, the exceptional significance of the thoughts of the Italian doctor and the already functioning in the world experience of preschool teachers and the producers of teaching aids, which are one of the key factors stimulating the independence of children in learning about the world, cooperating with them, was restored. With great self-denial and dedication, E. Łatacz obtained teaching aids, incredibly expensive, but beautifully manufactured in a Dutch factory, to educate candidates for the teaching profession and teachers already working in kindergartens, showing them materials of the highest aesthetic and methodological quality. At that time, she carried them in her backpack from classes at the university to teacher training institutions in the country, so that the participants of the first courses in the Third Polish Republic could practically learn, how to operate them and that they would inductively discover the fundamental rules of mathematics or their mother tongue like a child.

Soon, the first private Montessori kindergarten appeared in Lodz, and an assistant professor from the Department of Educational Theory at the University of Lodz, headed by the Author, - Małgorzata Miksza, contributed to the establishment of the first public kindergarten working in accordance with this pedagogy in that city. To this day, it hosts courses, trainings and workshops for those interested in alternative education, and the management has a serious problem with how to cope with the enormous pressure of hundreds of parents waiting for their child to be admitted to this facility each year. This is because there are too few such kindergartens in relation to the expectations and needs. However, the point is not that all kindergartens or even the majority of them should work on the basis of this model of education. The Montessori community in Łódź is the seat of the Polish Montessori Association.

Thanks to this, the educational value of this alternative was not diminished by conservative circles. ${ }^{2}$ Montessori education is not an

2 B. Śliwerski, Pedagogika dziecka. Studium z pajdocentryzmu, Gdańsk, GWP 2007. 
antagonistic approach, competitively excluding other models of preschool education. It requires teachers to additionally complete specialised education, practice continuous self-improvement and self-education, and perform many times more individual work (often at home) before each day of classes. This is because it is necessary to prepare appropriate development-related materials and the environment every day so that each child could develop according to their own potential.

The nature of this pedagogy was aptly presented by Zbigniew Łubieński, an educator, in 1937: Most modern educational methods make mistakes in two opposite directions: they either teach children many things without leaving enough room for their personal independence and initiative, or children are left with a great deal of freedom, without being provided with adequate (moral and technical) help, necessary to learn and the overall development. The Montessori method tries to find an indirect way, reconciling freedom with order, leaving far-reaching freedom of the creativity of the child, but at the same time establishing certain rules without which the teaching material would not be of proper use. ${ }^{3}$ We reexperience the art of discovering this pedagogy and developing it, updating it in new system conditions.

Polish teachers implement Montessori education into the native culture of preschool education, imbuing it with the latest psychological knowledge in the field of accelerating the development of children in the postmodern world and with the Polish cultural and spiritual tradition. The 21st century is important for the creative development of Montessori kindergartens and schools at every stage and level of education, so that the next, necessary transformation of education from traditional, static to dynamic, constructivist one, favouring the acquisition of lifelong learning skills, occurs. Polish masters of this pedagogy from various academic and educational centres in our country have created their own kindergartens, schools and special education institutions, which have become environments of fulfilled dreams of maximising own development potential

${ }^{3}$ After: E. Łatacz, op. cit., p. 150. 
for children of various social classes. From the beginning of the 1990s, as part of the cyclically organised International Conferences "Alternative Education - Dilemmas of Theory and Practice", each of the subsequent editions was enriched with Montessori education, so their participants present the world of education and upbringing of children in accordance with an integral approach to this process. ${ }^{4}$

\section{Montessori education in the pedeutological systematics of ideas}

Polish pedeutological thought is at the centre of the global debate on this subject, because Poland belongs to countries where the teaching profession is still perceived and treated as significant in the public space. As Henryka Kwiatkowska writes: Pedeutology is knowledge about the teacher (Greek: paideutes - teacher, logos-word, science). It is an increasingly independent area of pedagogics, dealing with issues relating to teachers: their personality, selection for a profession, education, training and professional work. ${ }^{5}$ During the transformation

${ }^{4}$ See: Edukacja alternatywna - dylematy teorii i praktyki, ed. B. Śliwerski, Oficyna Wydawnicza IMPULS, Cracow 1992 (2nd ed. amended, Cracow 1993); Pedagogika alternatywna - dylematy teorii, Wstęp, ed. B. Śliwerski, Oficyna Wydawnicza “Impuls", Cracow 1995 (2nd ed. Cracow 2000); Pedagogika alternatywna - dylematy teorii i praktyki, ed. B. Śliwerski, Oficyna Wydawnicza "Impuls", Cracow 1998; Edukacja alternatywna. Nowe teorie, modele badań i reformy, ed. J. Piekarski, B. Śliwerski, Oficyna Wydawnicza "Impuls", Cracow 2000; Nowe konteksty (dla) edukacji alternatywnej XXI wieku, ed. B. Śliwerski, Oficyna Wydawnicza "Impuls", Cracow 2001; Pedagogika alternatywna. Postulaty, projekty i kontynuacje, volume I. Teoretyczne konteksty alternatyw edukacyjnych $i$ wychowawczych, ed. B. Śliwerski, Oficyna Wydawnicza "Impuls", Cracow 2007; Pedagogika alternatywna. Postulaty, projekty i kontynuacje. Volume II. Innowacje edukacyjne i reformy pedagogiczne, Oficyna Wydawnicza "Impuls", Cracow 2007; Teoretyczne podstawy edukacji alternatywnej, ed. B. Śliwerski, Oficyna Wydawnicza "Impuls", Cracow 2009; Edukacja alternatywna w XXI wieku, ed. Z. Melosik, B. Śliwerski, Oficyna Wydawnicza "Impuls", Cracow 2010; Alternatywy w edukacji, ed. B. Śliwerski, A. Rozmus, Cracow-Rzeszów, Oficyna Wydawnicza "Impuls", University of Information Technology and Management in Rzeszów 2018.

${ }^{5}$ H. Kwiatkowska, Pedeutologia, Warsaw, WAiP 2008, p. 17. 
period, after a half-century break (in 1939-1989), three trends of scientific research on the teacher, which contribute to the cocreation of pedeutology as a specific sub-discipline in pedagogical sciences, developed. The Author does not mention here the fourth, practical area of development of this pedagogy, the authors of which, mainly teachers-practitioners, focused their attention on the methodology of upbringing, educating and caring for children based on the method of M. Montessori. ${ }^{6}$

In this paper, the Author focuses only on scientific pedeutological studies and research. The Author does this not only in connection with the cognitive category of key importance for the scientific debate in Lódź, the more so because also in the German lexicon of "Montessori Education", entries concerning the teacher/educator were distinguished. ${ }^{7}$ This proves the imperative of an integral approach to the anthropological, ethical, pedagogical and psychological assumptions of Maria Montessori education in affirmation or reception of her pedeutological views. Being an educator is a dynamic task of an adult as a guide for a child in the process of their upbringing. Orientation towards young people as human beings under formation, and as active beings with a tendency to learn independently requires an educational attitude that offers them supportive help. Montessori defines this attitude as love towards another person. ${ }^{8}$ The basis of the psychospiritual relationship between the educator and the child is the service for people with the use of appropriate techniques, thanks to which it is possible to learn from the child to reach their

${ }^{6}$ See: H.K. Berg, Maria Montessori - poszukiwanie życia razem z dziećmi. Odpowiedzi na aktualne pytania pedagogiczne, Kielce, Wydawnictwo Jedność Herder 2007; Erziehen mit Maria Montessori. Ein reformpädagogisches Konzept in der Praxis, Hrsg. H. Ludwig, Freiburg, Verlag Herder 1997; S. Guz, Edukacja w systemie Marii Montessori. Wybrane obszary ksztatcenia, volume 2, Lublin, Wydawnictwo UMCS 2015; M. Miksza, Zrozumieć Montessori, Oficyna Wydawnicza "Impuls", Cracow 1998; B. Stein, Teoria i praktyka pedagogiki Marii Montessori w szkole podstawowej, Kielce, Jedność 2003.

7 U. Steenberg, Handlexikon zur Montessori-Pädagogik, Ulm, Verlag Klemm \& Oelschläger, 1997.

8 Ibid., p. 48. 
childhood, understand their nature, creativity and spirituality. It is necessary to be able to help the child act independently, become a moral being, which requires the teacher to constantly refrain from their own interference.

\section{Three trends in research}

The first trend of research - is of a normative and model nature, and concerns the cultural and postulated status of a teacher, educator, primarily in their social and professional role, its importance in educating children and youth, but also self-education, self-development and self-improvement of teachers in connection with its performance in public and private education. These types of dissertations are of a postulative, idealising nature, largely referring to general and specific ethics, developmental psychology of the child, which are referred to in the dissertations of M. Montessori and their studies, as well as to the models of its fulfilment and alternative accomplishment implemented during the Second Polish Republic, thanks to numerous professionals. ${ }^{9}$

The second trend in empirical research concerns the psychosocial, political and economic conditions of the teacher's work, also in a comparative approach, referring to the results of international research in individual countries, as well as comparative studies. It is important because this first area of research is verified in terms of verifiability, reasonableness or possibility of implementation due to the independent variables. ${ }^{10}$

${ }^{9}$ Cf. N. Cicimirska, Moja ochronka, Lviv, Warsaw: Gubrynowicz i syn 1928; A. Gorycka-Wieleżyńska, Szkoła pracy samorozwojowej. Część teoretyczna, Warsaw, PSPS 1922; L. Jeleńska, Przygotowanie do życia przez szkołę, Poznań, Warsaw, Vilnius, Lublin, Księgarnia św. Wojciecha 1939; S. Marciszewska-Posadzowa, Instrukcja la ochroniarek, Poznań, Warszawa, Wilno, Lublin, Księgarnia św. Wojciecha b.r.w.; F. Pinesowa, System wychowawczy dr M. Montessori, Warsaw: DKP 1931; I.M. Schätzel, Idea wychowania przedszkolnego "Casa dei Bambini" jako szkółka wszechstronnej pracy dziecka", Lviv, PTP 1919.

${ }^{10}$ M. Królica, Znajomość wśród nauczycieli przedszkoli tez pedagogiki Marii Montessori i możliwości ich realizacji (unpublished text), [in:] International Scientific Conference. 
The third area of pedeutological, research, a juridical one, results from analysing, commenting and postulating in the light of the law of duty, standards of teachers' work as a result of the jurisdiction in force in the country, as well as established and permanently changed directives of pedagogical supervision or teacher's professional pragmatics. This is because it turns out that they not only determine the performance of this professional role, but also prevent the implementation of innovations or facilitate the introduction of alternative curricular, organisational and/or methodological solutions to (pre)school education in work with children and youth.

While the first two areas of pedeutology dominate the scientific and research work of representatives or teams of academic circles, the latter has a statist nature related to the interference of state authorities in the selection of teaching staff for the profession, their education and training, as well as strengthening individual development and professional promotion. Because of the integration of scientific knowledge, there is no need for a separate distinction between psychological, sociological, legal and educational research in the above-mentioned areas, as the 20th century started, among others, "a discovery of a teacher" as a unique profession that requires exceeding the borders of the specialist knowledge and taking into account existential functions that will affect the creation of the meaning of own life as well as the one of students, pupils or dependences. Socio-cultural, political, economic and technological changes in the postmodern world, including the most developed countries, generate a new perspective on teaching functions, which H. Kwiatkowska describes in the dimension of a necessary transition:

1. From the transfer of knowledge to teaching cognitive and existential independence,

2. From control to inspiring development,

3. From a simple message to introducing the student to the world of knowledge,

Pedagogika Montessori w Polsce i na świecie, Cracow, 29-30 September 2008, Conference materials, Cracow 2008. 
4. From the function of transferring knowledge to arranging information,

5. From the domination of intellect to the balance of the world of thoughts and feelings in school education and

6. From alternative to dialogue. ${ }^{11}$

When studying the works of Montessori, it is visible that there is no transition in the development of the identity of a teacher from a lower to a higher state. The educator is one who understands the limits of a child's learning and perceive themselves accordingly, as well as act accordingly as a facilitator of the sovereign development of a child, as one who humbly helps them to become HUMAN SELVES.

\section{A Montessori model of the teaching role}

It should be clearly stated that in the case of teachers of Montessori kindergartens and schools or education and care institutions in the field of therapeutic and special education, it is necessary reverse the type of relationship the Author presented in the title of this paper. For Maria Montessori, a teacher is first a PERSON, on whose existential structure of the role of an educator, and finally of a teacher is overlapped. Therefore, the triad in Montessori pedeutology must have a different direction: PERSON-EDUCATOR-TEACHER, which can be shortened to P-E-T. The educator is a being open to children and for children, and not narcissistically or elitistically focused on themselves or on the standards of behaviour established by others. They cannot focus their professional activity primarily on the legal conditions of its performance, which does not mean that they should ignore them, neglect them or act against them. A Montessori teacher must not be submissive in their activity to the interests of trade unions, the ministry of education and its supervisory staff, as well as political parties or movements, both those in power and in

11 Ibid., pp. 41-45. 
opposition. Probably for this reason it is easier for them to fully perform the role of a guide of children in their self-development when they work in a private kindergarten or school.

In Maria Montessori education, a duality of dominants is present, in which two perspectives of their experience and practice interpenetrate. This is because on the one hand, the teacher is for children, but on the other - Montessori education is a professional commitment of teachers to reorient their attitudes towards developing competence to work with children. In German education, the term of Kindzentriertepädagogik or Kinderorientiertepädagogik is used. According to the principles of this education, the child is the focal point of the interest of the educators in its individual, social, moral, aesthetic, spiritual and physical development. In turn, the teacher must be able to self-develop themselves and establish contact with themselves in such a way that they can achieve the assumed didactic and educational goals in an indirect, non-directive way. In fact, the reciprocity of attitudes should also permeate the attitudes of children, who also play the role of teachers within this education, while teachers are observers of children's activities. As Paul Epstein writes: The transformation of the school must occur simultaneously with the change of teacher preparation. This is because if a teacher is made an observer who is familiar with experimental methods, then they must be enabled to observe and experiment at school. And the basic principle of scientific education must be the freedom of the student. ${ }^{12}$

The normative approach to Montessori teaching comes from both the reception of the study of the Italian woman by educators trained in Poland and abroad in modern times, and from the educational practice through which they verified and emphasised the topicality of her pedagogics. The above-mentioned American expert and academic lecturer of this kind of education developed his own model of a Montessori teacher, defining it for short C.O.R.E. (Connect-to establish contact; Obtain-to obtain information, gain

12 P. Epstein, Z notatek pedagoga Montessori. Poradnik, translated by M. Madej, Oficyna Wydawnicza “Impuls”, Cracow 2014, p. 43. 
knowledge, Reflect - to reflect, to be reflective and Engage - to get involved), as crucial for the educational effectiveness of this education in school. ${ }^{13}$ Swedish kindergarten teachers - Kristina Skjöld Wennnerström and Mari Bröderman Smeds emphasise in their approach to children such qualities and attitudes of a Montessori teacher as: faith and trust in the abilities of a child, in their inner strength and willingness to develop their own skills, conscious development of own authority and setting an example for children, constant self-development, the ability to observe, change in contact with children, a sense of internal satisfaction with working with children, the competence to properly prepare the environment and guarantee the sense of security to children, the ability to observe, show respect to a child, share time with children, firmness, accuracy, patience, but also the ability to refrain from assessing and interrupting the child's activity or interfering with it. ${ }^{14}$

Sabina Guz, who analysed the scientific literature in terms of the preparation of professional requirements necessary to work with children, came to a similar typology of the specific characteristics of a Montessori teacher:

In order to fulfil their role properly, they should have numerous specific characteristics:

- to believe in the abilities of a child;

- to perceive them as active and learning beings, independently creating their own personality, not passive and receptive;

- to be convinced of the enormous importance of spontaneous activity for the development of a child;

- to show respect and loving understanding for the manifestations of their self-expression;

- to get rid of conceit, pride, haughtiness and prejudices against the child;

13 Ibid.

${ }^{14}$ K. Skjöld Wennnerström, M. Bröderman Smeds, Pedagogika Montessori $w$ przedszkolu $i$ szkole, translated by I. Łabędzka-Karlöf, Oficyna Wydawnicza "Impuls", Cracow 2007, pp. 83-84. 
- to do not show impatience and anger in situations when they make mistakes or do not comply with the applicable rules of social life;

- to be humble, patient, understanding, tactful and composed, but at the same time consistent and demanding;

- to be able to fade away into the background to give the child more space for free action and development;

- to have in-depth scientific knowledge about the child, their characteristics and laws of development, and constantly expand and update it;

- to be able to observe them with scientific accuracy and use the results of their observations in the upbringing process;

- to be a professional and personal authority for a child. ${ }^{15}$

\section{Models of research on a Montessori teacher}

The model of a Montessori teacher is very close to the Polish models of being a teacher, which were developed in the education of the period of the Second Polish Republic. For example, Ewa Łatacz showed similarity in the pedeutological views of Maria Grzegorzewska and Maria Montessori. They can be compared in order to perceive this in both normative approaches to being a teacher. ${ }^{16}$

In her historical and problem-focused monograph, the educator from Łódź made, among others, analysis of the pedeutological views of M. Montessori in terms of the perception of the teacher's image in Poland until 1939 and its presentation in the educational press published at that time. She drew attention not only to the reception of this kind of education from the time of its appearance in literature and the circulation of practical experience in the world in

${ }^{15}$ S. Guz, Metoda Montessori w przedszkolu i szkole. Ksztatcenie i osiagnięcia dzieci, Lublin, Wydawnictwo UMCS 2006, p. 69.

16 E. Łatacz, Podobieństwo metod pedagogicznych Marii Montessori i Marii Grzegorzewskiej, Acta Universitatis Lodziensis, Folia Paedagogica 2, 1999, pp. 15-19. 
Table 1. A comparison of the characteristics of a teacher as perceived by Maria Grzegorzewska and Maria Montessori

\begin{tabular}{|l|l|l|}
\hline $\begin{array}{l}\text { Comparative categories } \\
\text { in the model of a teacher }\end{array}$ & \multicolumn{1}{|c|}{$\begin{array}{c}\text { Maria } \\
\text { Grzegorzewska }\end{array}$} & \multicolumn{1}{|c|}{ Maria Montessori } \\
\hline $\begin{array}{l}\text { Condition for working } \\
\text { with children }\end{array}$ & Love for children & Love for children \\
\hline Intrapersonal attitude & Self-education & Education of one's own \\
\hline Interpersonal attitude & Responsibility & Responsibility \\
\hline Social competence & $\begin{array}{l}\text { Cooperation with } \\
\text { parents }\end{array}$ & $\begin{array}{l}\text { Cooperation with the family envi- } \\
\text { ronment of a child, and even the } \\
\text { social rehabilitation of parents }\end{array}$ \\
\hline Moral level & $\begin{array}{l}\text { High moral stan- } \\
\text { dards, humility }\end{array}$ & $\begin{array}{l}\text { High moral standards, being a role } \\
\text { model for a child }\end{array}$ \\
\hline Intellectual level & Wisdom & $\begin{array}{l}\text { mysticism and contemplation, reali- } \\
\text { ty research }\end{array}$ \\
\hline
\end{tabular}

Source: own elaboration based on: E. Łatacz 1999.

the first decades of its application in kindergartens and schools of the Second Polish Republic, but also to the criticism of some of its principles and their impact on Polish pedeutology. ${ }^{17}$

An original approach to constructing the teaching role of a Montessori teacher was proposed by Beata Bednarczuk, who reached for psychological concepts of a human being as a self-educating subject, with an integrated and mentally balanced personality, with inner locus of control, which is transgressive and reflective. The author used not only the latest approaches to the teaching profession of Michael Uljens, Maria Czerepaniak-Walczak, Ned A. Flanders, Ewa Filipiak, Bogusław Śliwerski, Dorota Gołębniak, Kazimierz Obuchowski, Kazimierz Dąbrowski, Józef Kozielecki, Anna Brzezińska, Stefan Kunowski, but also placed their isomorphic attributes in the Polish concept of a teacher of a class, school or education with individual program. ${ }^{18}$

17 E. Łatacz, Recepcja teorii pedagogicznej Marii Montessori w Polsce do roku 1939, Łódź, Wydawnictwo Uniwersytetu Łódzkiego 1996.

18 Cf. B. Śliwerski, Edukacja autorska, Oficyna Wydawnicza "Impuls", Cracow 1996 (2nd ed. 2008); idem, Problemy wspótczesnej edukacji, Warsaw, WAiP 2009. 


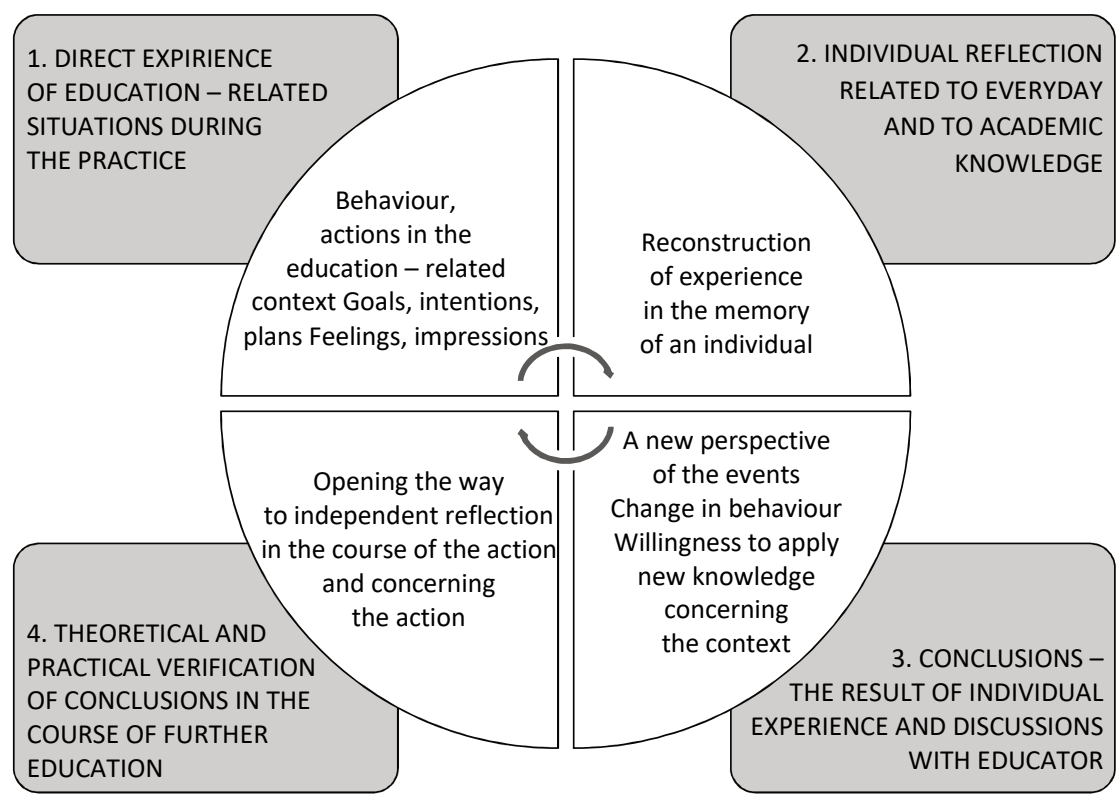

Fig. 1. Model of a reflective Montessori teacher (source: B. Bednarczuk, 2016, p. 112)

The second scope of research in the field of Montessori pedeutology has not developed in our country and is in statu nascendi probably because the movement of kindergartens and schools working in accordance with its principles is still at the stage of methodical preparation of teachers for work with children ${ }^{19}$ and the construction of curricula, which would be in line with the ministerial core curriculum for preschool education by educators. ${ }^{20}$ Perhaps it

${ }^{19}$ G. Badura-Strzelczyk, Pomóż mi zrobić to samemu. Jak wykorzystać idee Marii Montessori we wspótczesności, Oficyna Wydawnicza “Impuls”, Cracow 1998; P. Epstein, Z notatek pedagoga Montessori. Poradnik, translated by Magdalena Madej, Oficyna Wydawnicza “Impuls", Cracow 2014; M. Miksza, Zrozumieć Montessori, Oficyna Wydawnicza "Impuls", Cracow 1998; B. Stein, Teoria i praktyka pedagogiki Marii Montessori w szkole podstawowej, Wydawnictwo Jedność, Kielce 2003.

${ }^{20}$ A. Albinowska, A. Gaj, B. Lauba, J. Matczak, J. Sosnowska, R. Czekalska, Odkryjmy Montessori raz jeszcze... Program wychowania przedszkolnego opracowany na 
is related to the stereotype, popular in the interwar period, of thinking about Montessori education as only a certain method of education or an outdated concept, which has no place in the dynamically changing world of new technologies. Maria Królica performed a diagnosis of the level of knowledge of the principles of Montessori education among studying preschool teachers and their opinions on the possibility of practical use of this kind of education, and confirmed that they had elementary knowledge about the subject, but according to over $80 \%$ of the respondents there was no possibility to apply this kind of education in kindergartens due to the lack of appropriate teaching aids, architectural barriers and a large size of preschool groups. ${ }^{21}$

The third area of research concerns the empirical verification of the success and failures of Montessori education in Poland, but with a focus on children, their development and competence as a result of attending Montessori kindergartens or preschool departments. ${ }^{22}$ Therefore, it does not have a pedeutological nature, because the researchers did not pay attention to a teacher as the subject and coauthor of the changes taking place in children's development. Thus, in research projects, the discovery of a child is not accompanied by the discovery of a teacher, finding out what they are and whether their intrapersonal variables really constitute a significant contribution to the changes in the personality of children. In a way, it is assumed that if someone works in a Montessori kindergarten or school, they have internalised values and an adequate nature to prepare children for a widely understood environment, of which they are an active variable. Concentration on the infrastructural, material, technical and aesthetic preparation of the development

podstawie założeń pedagogiki Marii Montessori w Przedszkolu Miejskim nr 106 w Łodzi, Oficyna Wydawnicza “Impuls”, Cracow 2013.

${ }^{21}$ M. Królica, Znajomość wśród..., op. cit., pp. 11-17.

22 B. Bednarczuk, Osobowość autorska absolwentów klas Montessori w perspektywie doświadczeń i celów życiowych, Oficyna Wydawnicza "Impuls”, Cracow 2016; S. Guz, Metoda Montessori a zachowania społeczne dzieci, Wychowanie w Przedszkolu 2002, no. 9 , pp. 515-521. 
environment for children is crucial for this kind of education, but incomplete if the teacher becomes only its didactically correct arranger.

\section{Who is a Montessori teacher?}

In this kind of education, the independence of a child, their self-reliance and spiritual development as well as the ability to self-develop are closely related to the format of a teacher. The idealisation of their characteristics in the reception of the works of the Italian educator favours the neglect of the teacher in research on the quality of education. For example, Barbara Surma writes: Therefore, the ideal educator in the eyes of $M$. Montessori would be a person who, in addition to scientific knowledge, has a number of character traits, such as patience, humility, inner self-control and the ability to observe, use all available research tools, and above all, they will be characterised by a "spirit", or a fascination with life that they help to develop. It is the passion with which a teacher accompanies a child, forgetting about themselves. ${ }^{23}$ Therefore, Montessori teachers are not studied in Poland, assuming that, since they obtained the education and certificates appropriate for work in this type of institutions, they are probably what the founders of this kind of education would like them to be. Surma adds without reference to empirical data: The problem is to form such an educator who would help in life. Thus, the education of a teacher should not be only intellectual education.

M. Montessori places much greater demands on teachers, she is concerned with character education, spiritual formation and self-study. ${ }^{24}$

Therefore, we do not know who are, and what are Polish Montessori teachers. After all, is it not important whether they have knowledge about the genesis, creator and methodological solutions of this kind of education, but whether they are Montessori teachers

${ }^{23}$ B. Surma, Pedagogika Montessori - podstawy teoretyczne i twórcze inspiracje w praktyce, Łódź, Palatum 2008, pp. 65-66.

${ }^{24}$ Ibid., p. 66. 
in its full sense and their own attitude? Are they different and in which way from other kindergarten or school teachers who do not follow the ideas of this education in their work? This is important because, as Montessori wrote in her book "The absorbent mind", the first step in preparing a Montessori teacher is to prepare oneself to create the environment for the development of a child. Our education demands that the teacher, first of all, reflect on themselves and cleanse themselves of all the vices of tyranny. The complex of pride and anger, strengthened over the centuries, must be eradicated, the heart should be free from shackles. Above all, the teacher must learn to be modest in order to find love. Here is the attitude we must gain. This is the basis of internal balance without which there is no way to go any further. This is our inner preparation, our starting point and our goal. 25

It is not the best testimony about Polish and Italian teachers of Montessori kindergartens that out of 130 questionnaires sent in Poland by B. Surma - as part of her comparative research - only 67 were sent back, and out of 30 questionnaires distributed in Italy, it was only $16 .{ }^{26}$ However, this type of research adds nothing to our knowledge of teachers, since they are asked for opinions without the possibility of verifying their credibility. Their concentration both in Poland and Italy - on the method as a factor facilitating work with children confirms the instrumental approach to this kind of education. According to every fourth respondent a prepared teacher facilitates creative work, and it can be assumed that, after all, behind this preparation only the methodological sphere is hidden.

Although teaching is a profession, a social role, and thus also a set of universally applicable standards for performing certain activities, from a pedagogical point of view, if it is not a passion, then regardless of the educational concept it is based on, it leads to side

${ }^{25}$ M. Montessori, Umyst dziecka. Umyst absorbujacy, translated by Jacek Dąbrowski, Madras, 1949 [materials for internal use of the Polish Montessori Association], after: E. Sienkiewicz, Osobowość i zadania nauczyciela montessoriańskiego, www.edukacja. edux.pl/p-34834-osobowosc-i-zadania-nauczyciela-montessorianskiego.php access on 5.02.2018.

26 B. Surma, Pedagogika..., op. cit., pp. 101-102. 
effects that are harmful both to a teacher and their students. A teacher without passion is an executor of externally defined rules, a "worker" who produces an ordered product or service. Therefore, it is difficult for them to become a model, an idol, a significant person for their students, since they more often read bitterness, fatigue, discouragement, frustration, grief towards the whole world from their face, attitudes, or directly from the expressed statements, concerning the fact that they are or rather must be, a teacher. If someone in this role cares more about themselves and the opinion of their superiors than about those whom they should help in reading own talents, passions and possibilities for self-development, then they only maintain a negative image of their profession.

Teachers are not sovereigns of the implemented education, when they have to work under conditions established not by themselves, but by the educational supervision and the body running the institution. In the centralised system of public education, increasingly more often and more of them feel that they have to play unwanted roles in order to earn their living. Some people encounter in this profession the arrogance of pedagogical power, including the necessity to be submissive despite being aware of mistakes, nonsense or forced disguise. Such factors weaken the causative power of those teachers who - contrary to the existing solutions and limitations find in the teaching profession their own energy to live and act for the benefit of others, and also for themselves.

While (...) children form a subcultural whole as early as before they even begin their education at school and in this way seeds of collective opposition are sown ${ }^{27}$, teachers come to these institutions as individuals who, before they manage to transform into an understanding, solidary community, at the very beginning are subjected to disciplinary and normalising practices on the part of their superiors. Thus, as early as at the beginning of the teaching career, two socialisation worlds in authoritarian, hierarchical institutions are confronted not only by the very fact that the education process must take place

27 S. Richer, Socjologia i pedagogika, Kwartalnik Pedagogicznyp 1987, no. 4, p. 52. 
within specific legal, organisational and curricular frameworks, but also because almost every activity of the student depends rather not from them, but from the teacher's initiative 28 , and almost every activity of the teacher is monitored and evaluated by educational supervision and the grassroots parental feedback, as well as the rare but possible evaluation on the part of the students. Schools are highly bureaucratic organisations, largely governed by rules and official authority ${ }^{29}$, in which power is exercised in a legally sanctioned manner. No wonder that socialisation at school reflects different degrees and scopes of domination of some people over others, so that no one of the subjects of education could free themselves from the influence of the authorities.

One of the professional groups particularly at risk of mobbing in the workplace are employees of the education sector. The characteristics of a teacher's work, the need to adapt to the applicable rules, and a high rate of unemployment in this profession are just some of the features that may contribute to the occurrence of unethical, hostile and even aggressive behaviour in the teachers' environment. ${ }^{30}$ The nature of any power, in virtually all systems - democratic and non-democratic ones, is the possibility of "killing" a person in accordance with the law, also in public and non-public, educational and non-educational institutions. Mobbing is a form of "killing" another person "in velvet gloves" in a way that is imperceptible to the environment, through the constant tormenting, harassing without the use of physical force. ${ }^{31}$ As André Glucksmann writes: Sometimes white-hot and brutal,

${ }^{28}$ Ibid., p. 52.

29 Ibid.

30 A. Mościcka, M. Drabek, Mobbing w środowisku pracy nauczyciela, in: Psychospołeczne warunki pracy polskich nauczycieli. Pomiędzy wypaleniem zawodowym a zaangażowaniem, Oficyna Wydawnicza "Impuls", Cracow 2010, p. 79.

31 See W. Reich, Mordercy Chrystusa, translated by Henryk Smagacz, Warsawp Jacek Santorski \& CO Agencja Wydawnicza 1995; J. Carter, Wredni ludzie, translated by Justyna Kotlicka, Warsaw, Jacek Santorski \&CO Agencja Wydawnicza. Wydawnictwo System 1993; E. Fromm, Wojna w człowieku. Psychologiczne studium istoty destrukcyjności, Warsawp Jacek Santorski \&CO Agencja Wydawnicza 1994; P. Zim- 
other times cold and insidious, tireless hatred circulates around the world. Its fierce and stubborn spectre destroys private relations and public affairs. Every time it appears, we open our eyes wide in amazement. ${ }^{32}$

So what for will serve the substantive, didactic, planning, diagnostic, media-related, technical, educational, and even creative competence to a Montessori teacher ${ }^{33}$, if in relationships with students, their parents or educational supervision a barrier appears that invalidates or significantly weakens the meaning and value of their actions? The bureaucratization of educational system in the form of institutionalised rationality, requirements, uniformity of conduct and hierarchically divided power, resulting from the massification of education, flourished in our century and not always has supported the achievement of the well-being of the students. In addition, the "rights of institutions" were not always consistent with natural law. Therefore, the teacher takes full responsibility for recognising the law that separates human beings from the good of the person and is biased. The teacher must decide when statutory law does not apply, when it becomes evil or a recommendation to do evil (such situations are possible when the statutory law is assigned an absolute position). ${ }^{34}$

Scientific research of employees of various sectors and professional groups on the experience of mobbing by their superiors and colleagues places teachers in the highest place in terms of the intensity of this phenomenon. ${ }^{35}$ Teachers in a postmodern society need critical competence that allows them to understand themselves, to

bardo, Efekt Lucyfera. Dlaczego dobrzy ludzie czynia zło? Translated by Anna Cybulko, Joanna Kowalczewska, Józef Radzicki, Marcin Zieliński, Warsaw, WN PWN 2008.

32 A. Glucksmann, Rozprawa o nienawiśsi, translated by Wojciech Prażuk, Warsaw, Czytelnik 2008, p. 7.

${ }^{33}$ M. Kocór, Samoocena kompetencji zawodowych nauczycieli, [in:] O kompetencjach wspótczesnych wychowawców. Perspektywa praktyki edukacyjnej, Bydgoszcz, Wydawnictwo UKW w Bydgoszczy 2010.

${ }^{34} \mathrm{~W}$. Wołoszyn-Spirka, Kompetencje nauczyciela - wychowawcy w świetle filozofii realistycznej, [in:] O kompetencjach wspótczesnych wychowawców. Perspektywa praktyki edukacyjnej, Bydgoszcz, Wydawnictwo UKW w Bydgoszczy 2010, p. 40.

35 A. Mościcka, M. Drabek, Mobbing w środowisku pracy nauczyciela..., p. 81. 
determine their professional role and the possibility of finding optimal solutions to difficult situations. The declarative privilege of free choice of means and methods of education is not enough for them, since the centralised authorities of each political option in charge of the education system impose economic and social restrictions on teachers (e.g. too low wages, lack of funds for the purchase of teaching aids, increase in the size of student teams, etc.) or old patterns of didactic teaching models that contradict the sense and possibilities of real application of modern educational solutions.

Therefore, it is worth investigating who is a teacher in Montessori institutions? Are they different in which way from other preschool education teachers? Is Zygmunt Bauman right in saying that in the postmodern world they are only doorkeepers, and not idealists, missionaries, innovators or enthusiasts, that our teachers in a centralised school system are closer to being officials of public education, partial professionals, but not HUMAN SELVES? They used to have the luxury of being the sole doorkeepers of the edifice of knowledge - there was no other way. Nowadays they are only such informal doorkeepers, without a special uniform, without stripes - for there are many other ways to access knowledge. 36 Therefore, we do not know what the personal identity of Montessori teachers is, which is, after all, a secondary identity, to some extent added on the primary identity of the person who starts the profession. Nobody is born with this education. There is also no possibility of academical "cloning" of Maria Montessori in the process of educating candidates for teachers of these institutions. The personal identity of every human being (including the one being a teacher) is their understanding of their own existence, their life in response to the question of who they are. It is also related to such dimensions of human existence as authenticity, integrity, meaning, autonomy, self-respect, freedom, choice, responsibility and obligation.

${ }^{36}$ Koniec geografii, Z profesorem Zygmuntem Baumanem rozmawiaja Michat Pawet Markowski i Jacek Ziemek, Przekrój 2001, no. 4, p. 19. 
Identity understood in this way is also a social identity that structures the life of a human being in their relationship with other people. Social identity is our understanding of who we are and who other people are, and inversely - understanding of other people of who they are and who others, including ourselves, are. ${ }^{37}$ Therefore, what is the point of generating the concept of professional identity in this situation? Do we not create in this way a showy category? Since the identity of a human being is formed from the moment of their birth, from the moment when the child first obtains physical autonomy in the act of separation from the mother's body, and then, in the course of gaining experience and knowledge about themselves, when they shape the concept of " $I$ " as someone with relatively constant characteristics making them different from others 38 , does not "the introduction" of professional standards into an individual and creation of the desired teacher model lead to the formation of a professional identity as a showy identity, an identity assigned but excluding or conflicting with the personal perspective of human development?

The inner freedom of teachers is given to them along with their nature as part of their being, but in the order of perfection, that is, the degree of participation in freedom, it is proposed to them. Therefore, teachers should constantly free themselves, gain and consolidate their inner freedom, that is, freedom in choosing and achieving the intended goals, which as such will be the ability to resist external pressure. No one from the outside will provide them with freedom so necessary for their creative work, unless they themselves make an effort in this direction. However, in order to free oneself from the bondage of seduction, one must critically ap-

37 J.A. Bjųrkųe, Pomoc do samopomocy. Kofoeds School in Copenhagen. Institute for Social Work, translated by Beata Jagielska and Jan Kaczorowski, Kofoeds Skoleks Forlag, Kųbenhavn, Wydawnictwo “Żak” Warszawa 1997, p. 17.

38 J. Miluska, Iluzoryczna obecność tożsamości społecznej w edukacji politycznej w społeczeństwie obywatelskim, [in:] Przemiany społeczno-cywilizacyjne i edukacja szkolna problemy rozwoju indywidualnego i kształtowania się tożsamości, ed. T. Lewowicki, A. Szczurek-Boruta, B. Grabowska, Oficyna Wydawnicza "Impuls", Cracow 2005, p. 86 . 
proach the necessity of the existence of power in the achievement of the common good or happiness which is the education of children and youth. It is time to break with the identity of the professional role "assigned" by the authorities in favour of a "proposed" identity, which encourages creative exploration, self-determination and self-rule.

\section{References}

Albinowska A., Gaj A., Lauba B., Matczak J., Sosnowska J., Czekalska R., Odkryjmy Montessori raz jeszcze... Program wychowania przedszkolnego opracowany na podstawie założeń pedagogiki Marii Montessori w Przedszkolu Miejskim nr 106 w Łodzi, Oficyna Wydawnicza "Impuls", Cracow 2013.

Alternatywy w edukacji, ed. B. Śliwerski, A. Rozmus, Cracow-Rzeszów, Oficyna Wydawnicza "Impuls", University of Information Technology and Management in Rzeszów 2018.

Badura-Strzelczyk G., Pomóż mi zrobić to samemu. Jak wykorzystać idee Marii Montessori we wspótczesności, Oficyna Wydawnicza "Impuls", Cracow 1998.

Bednarczuk B., Osobowość autorska absolwentów klas Montessori w perspektywie doświadczeń i celów życiowych, Oficyna Wydawnicza "Impuls", Cracow 2016.

Berg H.K., Maria Montessori - poszukiwanie życia razem z dziećmi. Odpowiedzi na aktualne pytania pedagogiczne, Kielce, Wydawnictwo Jedność Herder 2007.

Bjųrkue J.A., Pomoc do samopomocy. Kofoeds School in Copenhagen. Institute for Social Work, translated by Beata Jagielska and Jan Kaczorowski, Kofoeds Skoleks Forlag, Kųbenhavn, Wydawnictwo “Żak” Warszawa 1997.

Carter J., Wredni ludzie, translated by Justyna Kotlicka, Warsaw, Jacek Santorski \&CO Agencja Wydawnicza. Wydawnictwo System 1993.

Cicimirska N., Moja ochronka, Lviv, Warsaw, Gubrynowicz i syn 1928.

Edukacja alternatywna - dylematy teorii i praktyki, ed. B. Śliwerski, Oficyna Wydawnicza "Impuls", Cracow 1992 (2nd ed. amended, Cracow 1993).

Edukacja alternatywna w XXI wieku, ed. Z. Melosik, B. Śliwerski, Oficyna Wydawnicza "Impuls", Cracow 2010.

Edukacja alternatywna. Nowe teorie, modele badań i reformy, ed. J. Piekarski, B. Śliwerski, Oficyna Wydawnicza "Impuls", Cracow 2000.

Epstein P., Z notatek pedagoga Montessori. Poradnik, translated by M. Madej, Oficyna Wydawnicza "Impuls", Cracow 2014.

Erziehen mit Maria Montessori. Ein reformpädagogisches Konzept in der Praxis, Hrsg. H. Ludwig, Freiburg, Verlag Herder 1997. 
Fromm E., Wojna w człowieku. Psychologiczne studium istoty destrukcyjności, Warsaw, Jacek Santorski \& CO Agencja Wydawnicza 1994.

Glucksmann A., Rozprawa o nienawiści, translated by Wojciech Prażuk, Warsaw: Czytelnik 2008.

Gorycka-Wieleżyńska A., Szkoła pracy samorozwojowej. Część teoretyczna, Warsaw, PSPS 1922.

Guz S., Edukacja w systemie Marii Montessori. Wybrane obszary ksztatcenia, volume 2, Lublin, Wydawnictwo UMCS 2015.

Guz S., Metoda Montessori a zachowania społeczne dzieci, Wychowanie w Przedszkolu 2002 no. 9, pp. 515-521.

Guz S., Metoda Montessori w przedszkolu i szkole. Kształcenie i osiagnięcia dzieci, Lublin, Wydawnictwo UMCS 2006.

Jeleńska L., Przygotowanie do życia przez szkołę, Poznań, Warsaw, Vilnius, Lublin, Księgarnia św. Wojciecha 1939.

Kocór M., Samoocena kompetencji zawodowych nauczycieli, [in:] O kompetencjach wspótczesnych wychowawców. Perspektywa praktyki edukacyjnej, Bydgoszcz, Wydawnictwo UKW w Bydgoszczy 2010.

Koniec geografii, Z profesorem Zygmuntem Baumanem rozmawiaja Michat Pawet Markowski i Jacek Ziemek, Przekrój 2001, no. 4.

Królica M., Znajomość wśród nauczycieli przedszkoli tez pedagogiki Marii Montessori i możliwości ich realizacji (unpublished text), [in:] International Scientific Conference. Pedagogika Montessori w Polsce i na świecie, Cracow, 29-30 September 2008, Conference materials, Cracow 2008.

Kwiatkowska H., Pedeutologia, Warsaw, WAiP 2008.

Łatacz E., Podobieństwo metod pedagogicznych Marii Montessori i Marii Grzegorzewskiej, Acta Universitatis Lodziensis, Folia Paedagogica 2, 1999, pp. 15-19.

Łatacz E., Recepcja teorii pedagogicznej Marii Montessori w Polsce do roku 1939, Łódź, Wydawnictwo Uniwersytetu Łódzkiego 1996.

Marciszewska-Posadzowa S., Instrukcja la ochroniarek, Poznań, Warszawa, Wilno, Lublin, Księgarnia św. Wojciecha b.r.w.; F. Pinesowa, System wychowawczy dr M. Montessori, Warsaw, DKP 1931.

Miksza M., Zrozumieć Montessori, Oficyna Wydawnicza “Impuls”, Cracow 1998.

Miluska J., Iluzoryczna obecność tożsamości społecznej w edukacji politycznej w społeczeństwie obywatelskim, [in:] Przemiany społeczno-cywilizacyjne i edukacja szkolna - problemy rozwoju indywidualnego i kształtowania się tożsamości, ed. T. Lewowicki, A. Szczurek-Boruta, B. Grabowska, Oficyna Wydawnicza “Impuls”, Cracow 2005.

Montessori M., Umyst dziecka. Umyst absorbujacy, translated by Jacek Dąbrowski, Madras, 1949 [materials for internal use of the Polish Montessori Association].

Mościcka A., Drabek M., Mobbing w środowisku pracy nauczyciela, [in:] Psychospołeczne warunki pracy polskich nauczycieli. Pomiędzy wypaleniem zawodowym a zaangażowaniem, Oficyna Wydawnicza “Impuls”, Cracow 2010. 
Nowe konteksty (dla) edukacji alternatywnej XXI wieku, ed. B. Śliwerski, Oficyna Wydawnicza "Impuls", Cracow 2001.

Pedagogika alternatywna - dylematy teorii i praktyki, ed. B. Śliwerski, Oficyna Wydawnicza “Impuls", Cracow 1998.

Pedagogika alternatywna - dylematy teorii, Wstęp, ed. B. Śliwerski, Oficyna Wydawnicza "Impuls", Cracow 1995 (2nd ed. Cracow 2000).

Pedagogika alternatywna. Postulaty, projekty $i$ kontynuacje, volume I. Teoretyczne konteksty alternatyw edukacyjnych i wychowawczych, ed. B. Śliwerski, Oficyna Wydawnicza "Impuls", Cracow 2007.

Pedagogika alternatywna. Postulaty, projekty i kontynuacje. Volume II. Innowacje edukacyjne i reformy pedagogiczne, Oficyna Wydawnicza "Impuls", Cracow 2007.

Reich W., Mordercy Chrystusa, translated by Henryk Smagacz, Warsaw, Jacek Santorski \& CO Agencja Wydawnicza 1995.

Richer S., Socjologia i pedagogika, Kwartalnik Pedagogiczny 1987, no. 4, p. 52.

Schätzel I.M., Idea wychowania przedszkolnego "Casa dei Bambini" jako szkótka wszechstronnej pracy dziecka", Lviv, PTP 1919.

Sienkiewicz E., Osobowość i zadania nauczyciela montessoriańskiego, www.edukacja.edux. $\mathrm{pl} / \mathrm{p}$-34834-osobowosc-i-zadania-nauczyciela-montessorianskiego.php access on 5.02.2018.

Skjöld Wennnerström K., Bröderman Smeds M., Pedagogika Montessori w przedszkolu $i$ szkole, translated by I. Łabędzka-Karlöf, Oficyna Wydawnicza "Impuls", Cracow 2007.

Steenberg U., Handlexikon zur Montessori-Pädagogik, Ulm, Verlag Klemm \& Oelschläger 1997.

Stein B., Teoria i praktyka pedagogiki Marii Montessori w szkole podstawowej, Wydawnictwo Jedność, Kielce 2003.

Surma B., Pedagogika Montessori - podstawy teoretyczne i twórcze inspiracje w praktyce, Łódź, Palatum 2008.

Śliwerski B., Edukacja autorska, Oficyna Wydawnicza "Impuls", Cracow 1996 (2nd ed. 2008); idem, Problemy współczesnej edukacji, Warsaw, WAiP 2009.

Śliwerski B., Pedagogika dziecka. Studium z pajdocentryzmu, GWP, Gdańsk 2007.

Teoretyczne podstawy edukacji alternatywnej, ed. B. Śliwerski, Oficyna Wydawnicza "Impuls", Cracow 2009.

Wołoszyn-Spirka W., Kompetencje nauczyciela - wychowawcy w świetle filozofii realistycznej, [in:] O kompetencjach wspótczesnych wychowawców. Perspektywa praktyki edukacyjnej, Bydgoszcz, Wydawnictwo UKW w Bydgoszczy 2010.

Zimbardo P., Efekt Lucyfera. Dlaczego dobrzy ludzie czynia zło? Translated by Anna Cybulko, Joanna Kowalczewska, Józef Radzicki, Marcin Zieliński, Warsaw, WN PWN 2008. 